\title{
Characterization and Localization of the Human Genes for Ribosomal Ribonucleic Acid
}

\author{
ROY D. SCHMICKEL (19) AND MECITHILDE KNOLLER \\ Departments of Pediatrics and Human Genetics, The University of Michigan, Ann Arbor, Michigan, USA
}

\begin{abstract}
Summary
The genetic sequence complementary to ribosomal RNA was separated from human DNA and its characteristics studied. Both $18 S$ and 285 sequences were located on the same isolated strand. DNA - rRNA hybrids have a melting temperature of $80^{\circ}$ or $4^{\circ}$ less than that of native ribosomal DNA. Ribosomal genes behave as a satellite when complexed with $\mathrm{Ag}^{+}$in the Cs..SO, gradient. With in situ hybridization, these rRNA genes can be shown to chromosomally translocate. The study of a highly fluorescent chromosome indicates that the ribosomal DNA does not contribute to the fluorescent nature of the secondary constrictions. This study examines the molecular organization of human ribosomal genes. The chromosomal inheritance of these genes is explored by in situ hybridization.
\end{abstract}

\section{Speculation}

Human ribosomal DNA represents a well defined repetitious DNA which can vary quantitatively in normal and abnormal ways. This DNA should be representative for studying the inheritance patterns of repetitious DNA.

Increased understanding of human genes will result from the ability to quantitate and characterize the properties of specific human genes and to correlate DNA changes with changes seen in cytogenetic preparations and clinical situations. We describe a sequence of thermal fractionation, molecular hybridization, and density gradients for the enrichment and study of the genetic sequence complementary to human ribosomal RNA. In situ hybridization was used to look at the rearrangement of $r R N A$ genes which can result from exchange between nonhomologous chromosomes. Molecular hybridization and in situ hybridization was facilitated by the preparation of highly purified rRNA which was synthesized and labeled in human fibroblasts auxotrophic for uridine.

Quantitation of ribosomal RNA genes indicates that the diploid human cell contains $300-400$ rRNA genes $(2,8,14)$. The DNA which is complementary to rRNA represents about ().014\% of the total DNA in a human cell. This DNA sequence has guanosine + cytosine $(G+C)$ content of $6+\%$, which is $25 \%$ higher than that of the average cellular DNA. The relatively high number of $\mathrm{G}+\mathrm{C}$ pairs in ribosomal DNA (rDNA) is responsible for its relatively high buoyant density and thermal stability, and provides a rationale for the enrichment of that specific DNA as previously described (14).

\section{MATERIALS AND METHODS}

\section{DNA PREPARATION}

DNA was prepared from surgically obtained spleens as described previously (14). The size of isolated DNA was determined by the method of Mandel and Hershey (12) using P22
DNA (molecular wt $2.7 \times 10^{i}$ ) as standard and by direct measurement from electron microscopy photographs using lambda phage as a standard. The molecular weight of the purified DNA was $5-60 \times 10^{6}$.

\section{ENRICHMENT OF IDNA BY THERMAL FRACTIONATION}

Enrichment of the rDNA can be achieved by partial melting of the DNA. Since the rDNA is relatively $(G+C)$-rich it resists melting at temperatures which denature the bulk of human DNA. The DNA in 0.1 SSC (a solution of $0.15 \mathrm{M} \mathrm{NaCl}$ and (0.0) $15 \mathrm{Na}$ citrate) was heated to $80^{\circ}$ for $5 \mathrm{~min}$ and slowly cooled. The DNA solution was adjusted to a concentration of $3.3 \times \mathrm{SSC}$ and chromatographed on nitrocellulose as previously reported (14). Approximately one-sixth of the DNA was not denatured and therefore passed through the column unretarded.

\section{PREPARATION OF rRNA}

Because of the low concentration of sequences complementary to rRNA in human DNA, the assay of rDNA requires a high specific activity of the hybridizing rRNA and low levels of nonspecific binding. We have utilized fibroblasts from a patient with orotic aciduria to achieve a high specific activity of the rRNA. These cells are auxotrophic for uridine as described by Krooth (11) sinee they lack both orotidine-5'-monophosphate pyrophosphorylase and orotidylate decarboxylase. Although they exhibit some growth in uridine-free medium, the requirement for uridine is absolute when the cells are grown in media with an adenosine concentration of $15 \mu \mathrm{g} / \mathrm{ml}$.

Ribosomal RNA was prepared by incubating orotic aciduria fibroblasts in the Blake bottle with medium containing $15 \mu \mathrm{g} / \mathrm{ml}$ adenosine, $2 \mathrm{mCi}[5,6-3 \mathrm{H}]$ uridine $(56 \mathrm{Ci} / \mathrm{mmol}$, AmershamSearle) in $50 \mathrm{ml}$ Eagle's minimum essential medium (MEM, Difeo) and $5 \%$ dialyzed fetal calf serum. The cells were incubated for $36 \mathrm{hr}$. The medium was then exchanged for nonradioactive medium containing $15 \mu \mathrm{g} / \mathrm{ml}$ uridine for $12 \mathrm{hr}$. This procedure was necessary to "chase" the unstable cellular RNA. The cells were removed from the flask with trypsin incubation and the ribosomes were purified by a modification of Blobel's procedure (1). This included pelleting the ribosomes in a step gradient, dissociating the subunits with puromycin, repelleting the subunits, extracting the rRNA by phenol, and isolating $18 \mathrm{~S}$ and $28 \mathrm{~S}$ RNA by a continuous sucrose gradient. This procedure produced rRNA of a specific activity of $0.7-2.0 \times 10^{6 ;} \mathrm{cpm} / \mu \mathrm{g}$. lybridization with this rRNA showed saturation of the DNA at an RNA/DNA ratio of 0.1 and no increase at an RNA/DNA ratio 5 times higher.

\section{IIYBRID FORMATION}

Ten milliliters of the DNA (0.116 $\mathrm{mg} / \mathrm{ml})$ which had been thermally fractionated was denatured by heating to $100^{\circ}$ for 3 min. cooled to $72^{\circ}$, and adjusted to $+X$ SSC. Radioactive $r R N A$ $\left(0.5 \mathrm{mg}\right.$, specific activity $\left.2.1 \times 10^{6} \mathrm{cpm} / \mu \mathrm{g}\right)$ was added to the solution and incubated for 1 hr at $72^{\circ}$. 
IDNA ASSAY

The rDNA was fixed to nitrocellulose dises and assayed by the method of Gillespic and Spiegelman (7). When hybrids were formed in solution, the hybrids were absorbed by filtration through nitrocellulose discs (Schleicher and Schuell). The discs were subsequently digested with pancreatic RNase and rinsed in $2 \times$ SSC. The hybrids were quantitated by liquid scintillation counting of the radioactivity remaining on the nitrocellulose discs.

\section{CsCl CENTRIFUGATION}

$\mathrm{CsCl}$ was added to the DNA solution to give a density of 1.70 $\mathrm{g} / \mathrm{ml}$. The samples were centrifuged in a 50 rotor (Beckman) at $33,000 \mathrm{rpm}$ for $72 \mathrm{hr}$ at $25^{\circ}$. Fractions were collected from the bottom.

\section{IN SITU HYBRIDIZATION}

In situ hybridization was performed by the procedure developed by Gall and Pardue (6). Metaphase chromosomal preparations on glass microscope slides were denatured at an alkaline $\mathrm{pH}$ and incubated with $50 \mu \mathrm{l}$ rRNA $(0.2 \mu \mathrm{g} / \mathrm{ml})$, digested with RNase, and dipped in Kodak NTB-2 film cmulsion. The preparations were exposed for 60 days, developed, photographed, and karyotyped.

\section{FRACTIONATION OF HUMAN DNA IN $\mathrm{Ag}^{+}-\mathrm{Cs}_{2} \mathrm{SO}_{4}$}

Human DNA was prepared as above, and $\mathrm{Ag}_{2} \mathrm{SO}_{4}$ added at an Ag:DNA-PO, ratio of 0.27 as described by Brown. Wensink. and Jordan (4). C..2SO, was added to obtain a density of $1.57 \mathrm{~g} /$ $\mathrm{ml}$ and the solution centrifuged at $33,0(0) \mathrm{rpm} \times 72 \mathrm{hr}$ at $25^{\circ} \mathrm{in}$ a 50 rotor (Beckman). Fractions were collected from the top.

\section{RESULTS}

Purified DNA $(1.16 \mathrm{mg})$, which had been partially denatured by beating to $S\left(0^{\circ}\right.$, was enriched for rDNA by nitrocellulose chromatography as described (14). This enriched rDNA was hybridized with tritium-labeled rRNA and the hybrids were isolated on a CsCl gradient (density $1.72 \mathrm{~g} / \mathrm{ml}, 35 .(0)(0) \mathrm{rpm}$ for $72 \mathrm{hr}$ ). After centrifugation a biomodal distribution of the hybrids was seen (Fig. 1A). About one-fifth of the radioactivity was associated with the main band of DNA and the remainder with a peak whose density exceeded that of single stranded DNA. After recentrifugation of this denser DNA, the specific gravity of the hybrids was measured. The peak specific gravity was $1.75 \mathrm{~g} / \mathrm{ml}$ (Fig. $1 B$ ). Native ribosomal DNA has a buoyant density of 1.72 and the denatured form is 1.73 (14).

In order to determine the linkage of the seyuences of $18 \mathrm{~S}$ and $28 S$ RNA in the isolated hybrids, we performed a two-step hybridization. Unlabeled 28S RNA (0.15 mg) was hybridized with $1.5 \mathrm{mg}$ of DNA. This DNA was then centrifuged as described in "Methods." An equal sample of DNA which had been denatured but not hybridized was centrifuged as a control sample as has been described by Brown and Weber (3). The DNA from each tube was collected in the four fractions indicated in Table 1 and hybridized with $18 \mathrm{~S}$ rRNA. The control DNA with a density greater than 1.74 did not hybridize with 1 SS RNA. IOWever, the prehybridized DNA hybridized with 2 ng of $18 \mathrm{~S}$ RNA (4, ()45 cpm), as seen in Table 1 . This would indicate that DNA which had been hybridized with 28S RNA and isolated as a hybrid could be further hybridized with $18 \mathrm{~S}$ RNA. These isolated segments of DNA had sequences complimentary to both $18 \mathrm{~S}$ and $28 \mathrm{~S}$ RNA.

Figure 2 shows the melting temperature of RNA. DNA hybrids. Tritium-labeled rRNA - DNA hybrids isolated as in Figure 1 were dialyzed extensively against $0.1 \times$ SSC and diluted to 10

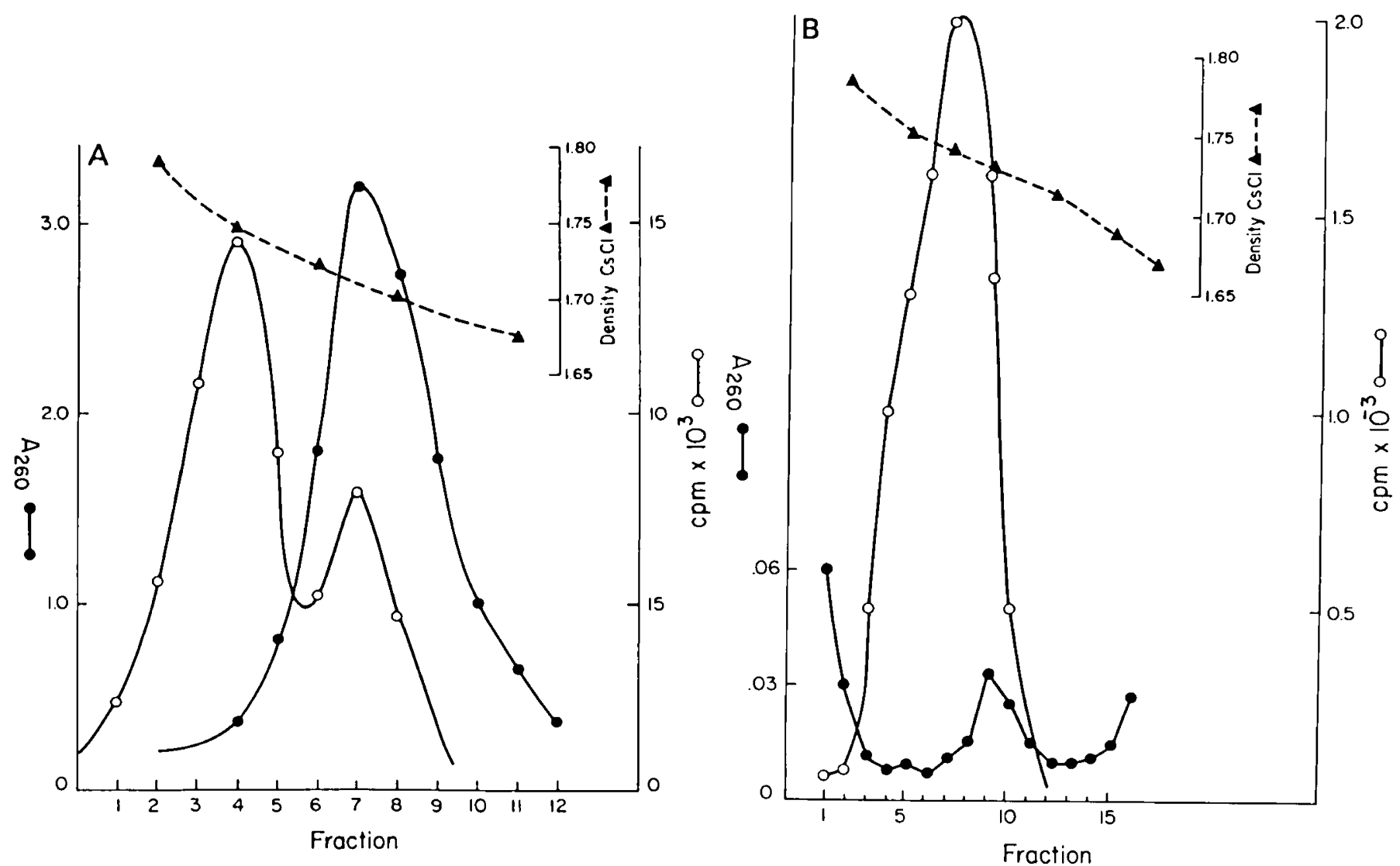

Fig. 1. A: centrifugation of rRNA-DNA hybrids. Fractions were collected from the bottom of a 10 -mi CsCl gradient. The counts per min of the ["H/rRNA. DNA hybrids wich were RNase resistant, trichloracetic acid-precipitable, and absorbed to nitrocellulose discs $(\mathrm{O}-\mathrm{O})$. Density was measured by a refractometer $(\mathbf{\Delta}-\mathbf{A})$. The optical density of each sample was determined by ultraviolet spectrophotomer at $A_{2 t a i}(\bullet-\infty)$. $B$ : recentrifugation of fractions 2,3 , and 4 of $A$. 
Table 1. ISS rRNA hybridization with DNA which had been previously hybridized with $28 S$ rRNA

\begin{tabular}{lcccc}
\hline & \multicolumn{4}{c}{ DNA fraction } \\
\cline { 2 - 5 } & 1 & 2 & 3 & 4 \\
\hline $\begin{array}{l}\text { Density, g/ml } \\
\mu \mathrm{g} \text { DNA in frac- } \\
\text { tion }\end{array}$ & $1.61-1.66$ & $1.66-1.70$ & $1.70-1.74$ & $1.74-1.81$ \\
Counts per min \\
hybridized \\
with 18S
\end{tabular}

1 Too little DNA to detect by optical density.

2 Thirty micrograms of DNA from each fraction was fixed to nitrocellulose and hybridized with $18 \mathrm{~S}$ RNA. Counts per min represent counts after hybridization that were resistant to RNase.

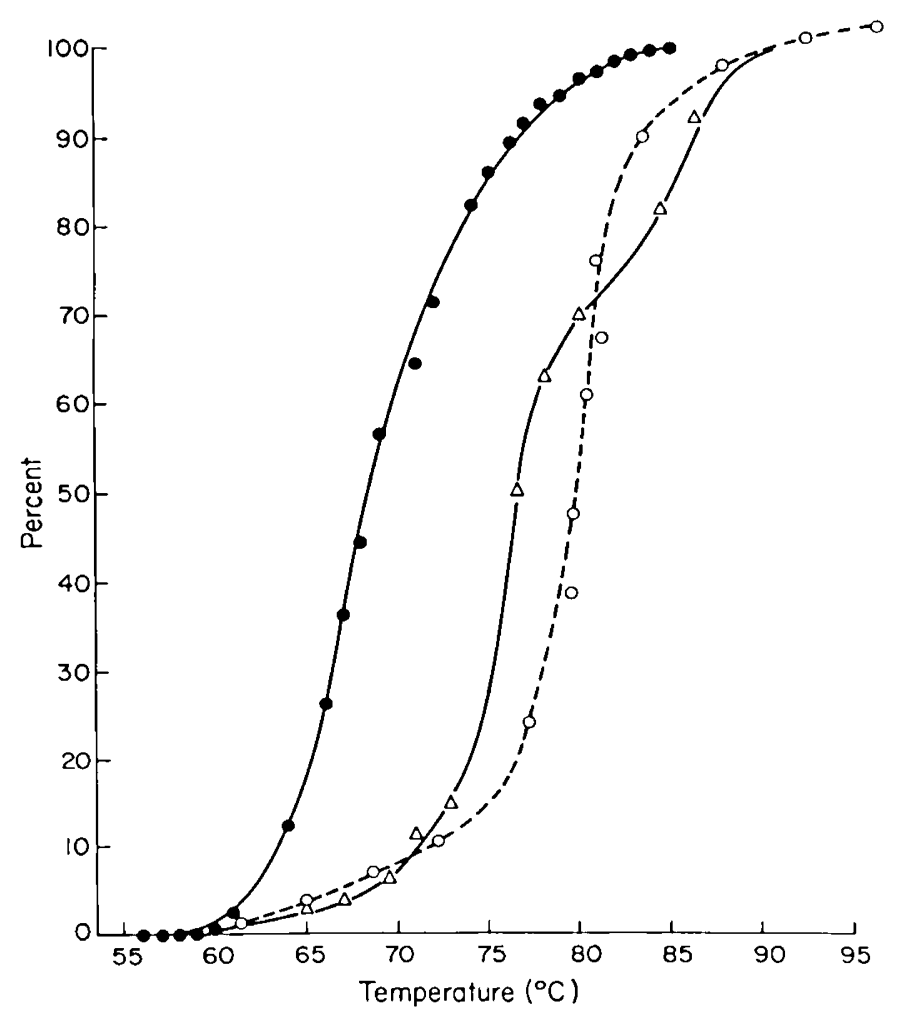

Fig. 2. Comparison of hyperchromic transition and melting of human DNA to the melting temperature of rRNA.DNA hybrids. DNA was melted in a heated spectrophotometer with the increase in absorption recorded as the chamber temperature increased (-—) Melting of DNA was determined by determining the pereentage of labeled DNA which absorbed to nitrocellulose after heating to the indicated temperature in $0.1 \times \operatorname{SSC}$ and quickly cooling in $3 \times \operatorname{SSC}(\triangle-\triangle)$. The melting temperature of rRNA.DNA was determined as described in "Materials and Methods" $(\mathrm{O}-\mathrm{O})$.

$m \mathrm{in} 0.1 \times \mathrm{SSC}$. As the temperature of the solution of hybrids was increased from $55^{\circ}$ to $1000^{\circ} .0 .5-\mathrm{ml}$ samples (containing 600 cpm) were quickly cooled in $5 \mathrm{ml}$ of $3.3 \times$ SSC. These samples were assayed for the pereentage of tritim-labeled rRNA which remained in the hybrid form by measuring retention to nitrocellulose discs. The rRNA rDNA hybrids meled rather quickly at $80^{\circ}$. From a previous experiment. we know that native rDNA begins to melt at $84^{\circ}(14)$. This would indicate that rDNA is more resistant to thermal denaturation than are DNA rRNA hybrids. It would suggest that the DNA complementary to rRNA is separated by DNA sequences with a higher $G+C$ content. The DNA sequences complimentary to precursor $45 \mathrm{~S}$ RNA could be responsible for the gene stability.

The ribosomal DNA is found as a light satellite in a $\mathrm{Ag}^{+}-$ $\mathrm{CS}_{2} \mathrm{SO}_{4}$ gradient. Silver was added to $4 \mathrm{mg}$ human DNA and centrifuged with Cs.g $\mathrm{SO}_{4}$ as described in "Materials and Methods." Fratctions were pumped from the top of the gradient and 30 $\mu \mathrm{g}$ DNA from each was denatured, fixed to nitrocellulose disc, and hybridized with $2 \mu \mathrm{g} \mathrm{rRNA}$ (specific activity $100 \mathrm{cpm} /$ ng) at $64^{\circ}$ for $15 \mathrm{hr}$. As seen in Figure 3 , the rDNA was located on the light side of the curve. This satellite property is demon-

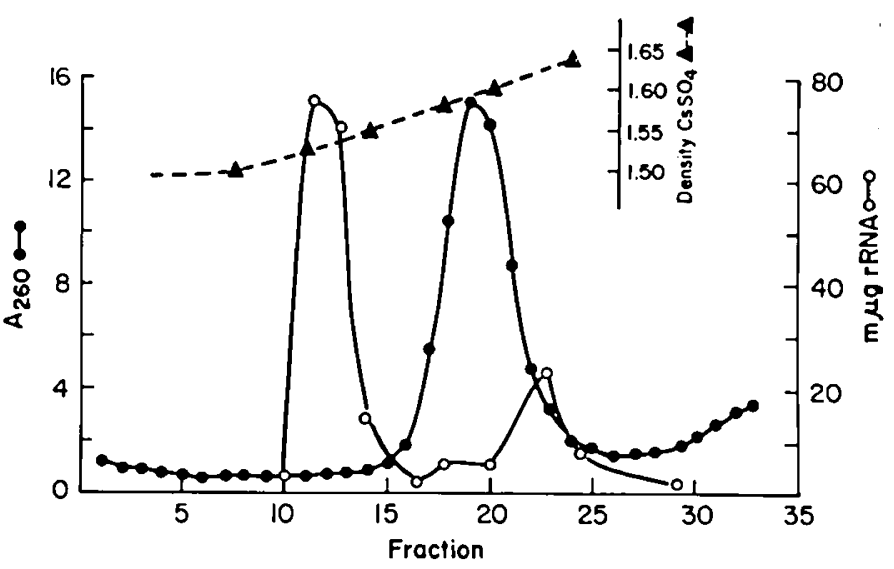

Fig. 3. Complexing human DNA with $\mathrm{Ag}^{+}$in a $\mathrm{Cs}_{2} \mathrm{SO}_{4}$ gradient and detection of rDNA. rDNA was detected by hybridizing it with labeled rRNA as described in "Methods." The hybridized [3I]RNA, which was RNase resistant and trichloroacetic acid-precipitable, was counted in liquid scintillation. $\mathbf{\Delta - \Lambda}$ : grams per $\mathrm{ml}$ buoyant density of fractions; -—: OD at $260 \mathrm{~nm} ; \mathrm{O}-\mathrm{O}$ : nanograms of rRNA hybridized to 30 $\mu \mathrm{g}$ DNA.

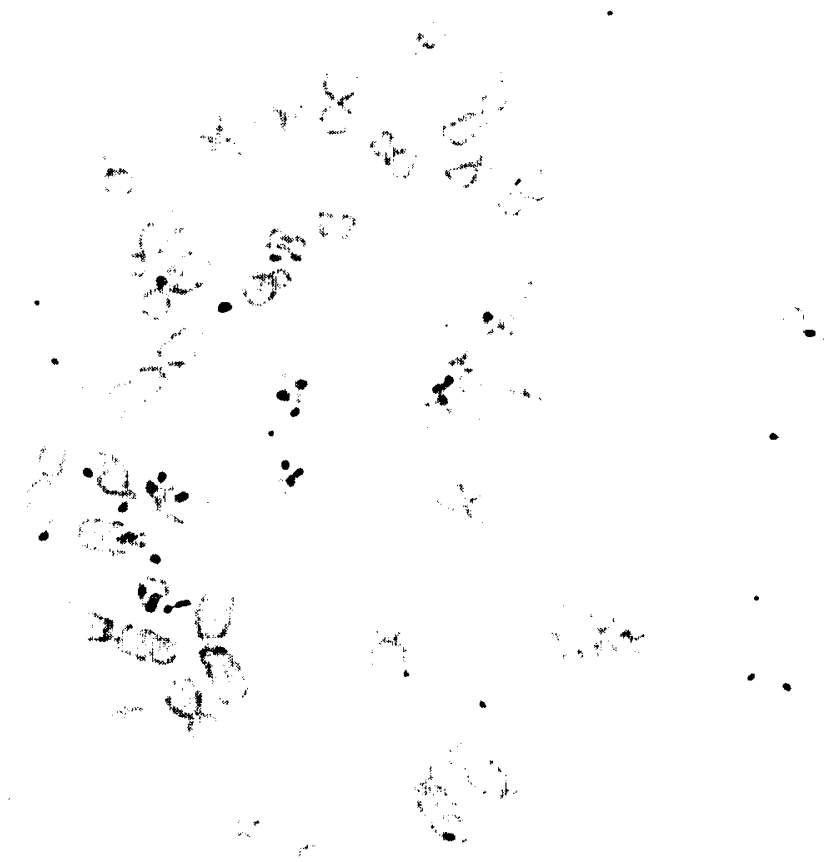

Fig. 4. Autoradiograph of a normal karyotype hybridized with rRNA. The chromosomes were denatured with $0.07 \mathrm{M} \mathrm{NaOH}$ and hybridized with $50 \mu \mathrm{l}\left[{ }^{3} \mathrm{H}\right] \mathrm{rRNA}(0.2 \mu \mathrm{g} / \mathrm{ml})$. The slides were dipped in emulsion and incubated for 60 days before development. Twenty-seven grains are over the short arms of the acrocentric chromosomes, whereas 4 grains are scattered randomly over the other chromosomes. 
strated only when the DNA has a high molecular weight after the extraction procedure. Some of the ribosomal DNA does not act as a satellite and the proportion which bands with the bulk DNA may represent small rDNA segments. When electron microscope photographs demonstrated that the molecular weight of the DNA was less than $5 \times 10^{6}$ daltons, separation was not possible.

\section{IN SITU HYBRIDIZATION}

Because of the high purity, specific activity and DNA saturating characteristics of the $r$ RNA prepared from the uridine auxotrophic cells, we utilized this rRNA for the localization of rDNA sequences in various human chromosome preparations. Figure 4 shows an example of the in situ hybridization on a normal human karyotype. Twenty karyotypes were examined and the number of silver grains over each chromosome was counted (Table 2). Of 1.823 grains counted, 1,362 were touching the short arms of the $D$ and $G$ groups chromosomes. Seventy-two pereent of the grains were over the short arms of the acrocentric chromosomes although the short arms of the acrocentric chromosomes represent only $2 \%$ of the total chromosomal mass. No other chromosomal area showed labeling of homologous chromosomes or sister chromatids in any of the karyotypes. Although the individual chromosomes could not be identified, the distribution of grains between the $D$ and $G$ groups was 1,092 to 761 , respectively, which is proportional to their representation. Non-nucleolar chromosomes were not labeled by in situ hybridization.

The $D$ and $G$ groups which show satellite association also tend to have continuous grains between the chromosomes (9). This would suggest that the rDNA is in an extended form even at metaphase. We have looked for evidence of rDNA in chromosomes which are not extended such as in Robertsonian translocation. Figure 5 shows an example of this. In 10 cells with a $D / G$ karyotype, there was no significant hybridization over any homologous pairs of the entire $C$ group chromosomes of which the Robertsonian translocation was a part. Although a total of 518 grains were counted over the $D$ and $G$ chromosomes in these cells, only 32 grains were counted over the various $C$ group chromosomes. This would indicate that, in this particular case, there is no detectable rDNA in the translocated chromosome.

A family we have followed has a balanced $15 \mathrm{p}+/ 16 \mathrm{p}-$ translocation in several family members (15). Although the 15 $p+$ chromosome is difficult to distinguish under conditions in in situ hybridization, the altered 16 is easily detected because of its

\section{Table 2. Autoradiographic analysis of rRNA hybridization to human chromosome preparations}

\begin{tabular}{|c|c|c|c|c|}
\hline No. cells examined & Karyotype & \multicolumn{2}{|c|}{ Grains over chromosomes } & Probability' \\
\hline 20 & Normal & $\frac{10 D+G}{1362}$ & $\frac{36 \text { other }}{461}$ & $<0.001$ \\
\hline 10 & $D / G$ translocation & $\frac{9 \mathrm{D}+\mathrm{G}}{518}$ & $\frac{15 \mathrm{C} \text { group }}{32}$ & $<0.001$ \\
\hline 11 & $16 / 15$ translocation & $\frac{116}{28} p=$ & $\begin{array}{c}5 \text { other E group } \\
2\end{array}$ & $<0.001$ \\
\hline 15 & Fluorescent 15 & $\frac{\text { Variant } 15}{0}$ & $5 \frac{5 \text { other D group }}{168}$ & $<0.001$ \\
\hline
\end{tabular}

\footnotetext{
${ }^{1}$ Chi square.
}

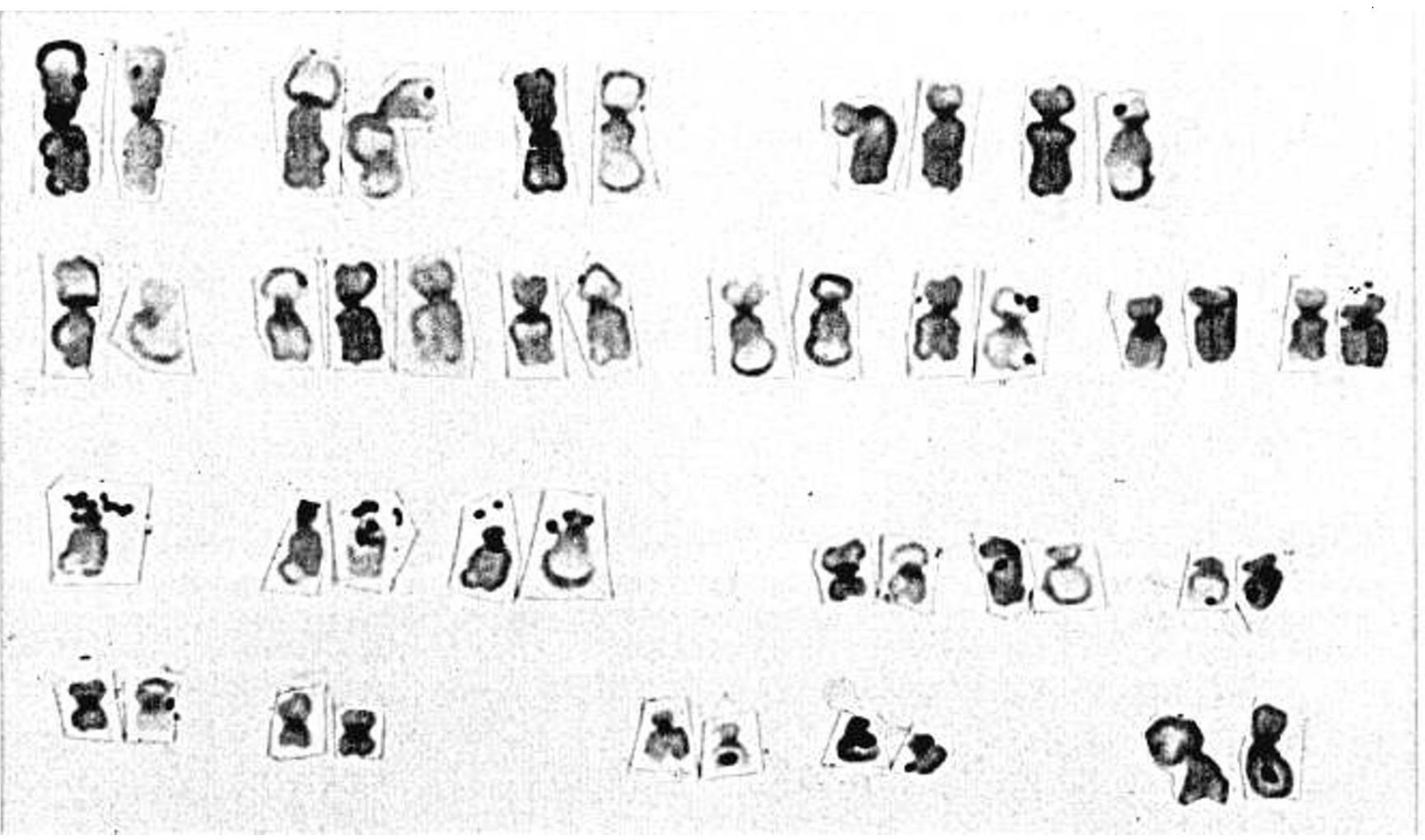

Fig. 5. A karyotype prepared as in Figure 4 from an autoradiograph of a patient with Down's syndrome and a 46 XX. D/G karyotype. The D/G translocation chromosome is similar in morphology and has been aligned with the metacentric $C$ chromosomes. The D/G translocated chromosome does not show labeling. 
KARYOTYPE
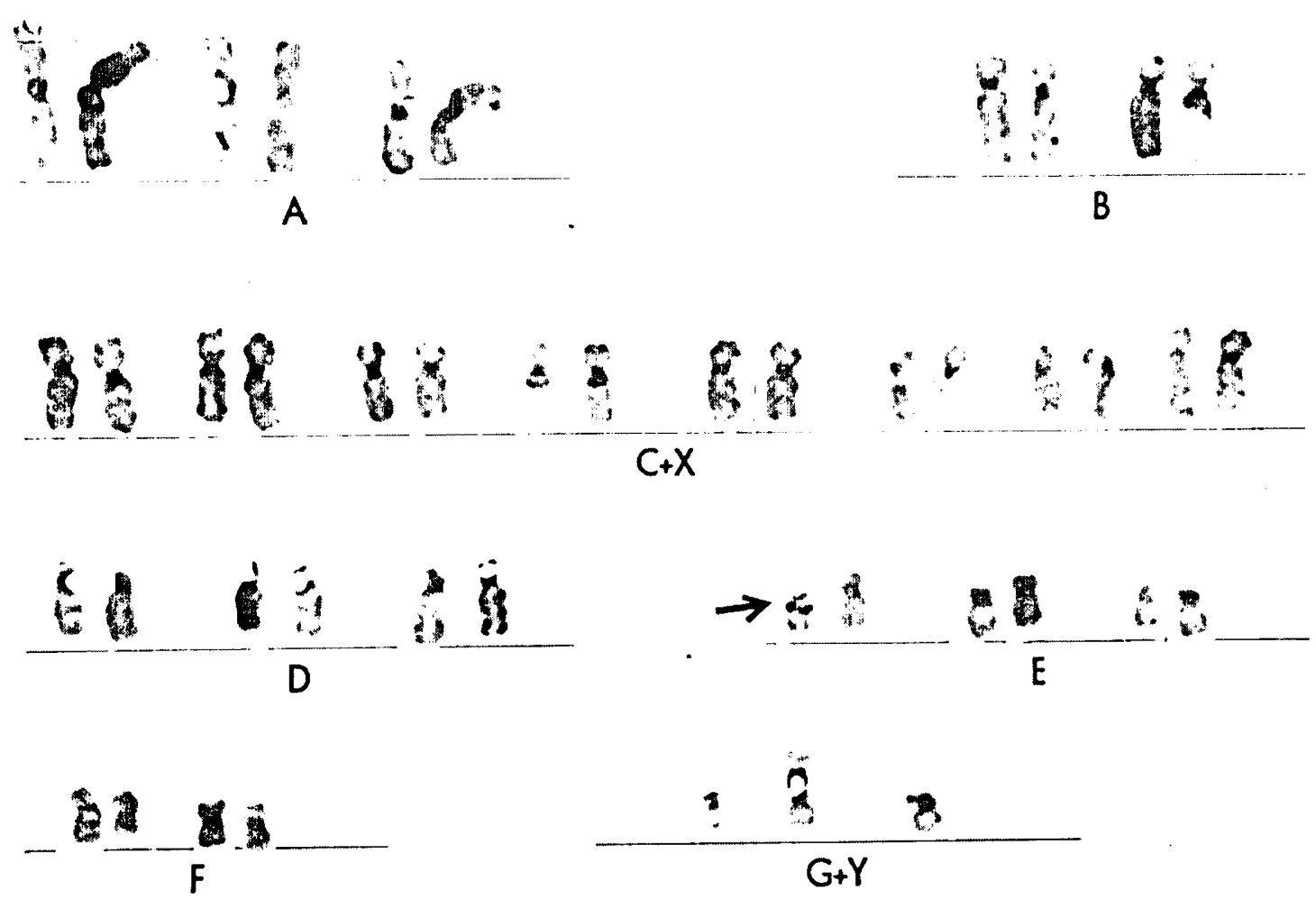

Fig. 6. Autoradiographic karyotype of a normal person with a balanced $15 / 16$ translocation. Autoradiography showed hybridization consistently over the $16 p$ - chromosome (as shown by the arrow).

size and the presence of a dark staining band in the y arm (Figs. 6 and 7). We found that this number 16 chromosome consistently hybridized with rRNA although none of the other E group chromosomes did. This would suggest that ribosomal genes from chromosome 15 were translocated to chromosome 16.

Finally, because of the unusual binding properties of rDNA with $\mathrm{Ag}^{+}$, we attempted to answer the question whether rDNA is responsible for or associated with the fluorescence of the $D$ and $G$ group satellites. We have studied a variant chromosome 15 exhibiting bright fluorescence of the short arm. It could easily be distinguished from the other chromosomes in the in situ preparations (Figs 8 and 9). In 15 karyotypes from this person, no in situ hybridization with rRNA was seen with any portion of the highly fluoreseent chromosome. This would suggest that the chromosome lost most of its rDNA and that the fluoreseence of the short arms of the acrocentric chromosome is not dependent on the rDNA. This chromosomal variant was not associated with any physical or growth abnormality of the individual.

\section{DISCUSSION}

These studies help to characterize the human ribosomal genes. They suggest that ribosomal genes are clustered and tandemly repeated. The rDNA is found in a narrow CsCl band at a density of $1.72 \mathrm{~g} / \mathrm{ml}$. If rDNA was interspersed randomly with other DNA, one could expect it to be located on DNA fragments of various densities. The $18 S$ and $28 S$ RNA are found on the same rDNA fragments as shown by the two-step hybridization experiment. Our melting data indicates that the $18 \mathrm{~S}+28 \mathrm{~S}$ rDNA is interspersed with DNA of a high $G+C$ content. The melting temperature of native rDNA is appreciably higher than that of rRNA.rDNA hybrids. Other evidence for interspersion of DNA between the $18 \mathrm{~S}$ and $28 \mathrm{~S}$ RNA is that the rRNA - rDNA molecules formed at a high $R N A / D N A$ ratio have a buoyant density of approximately 1.75 . This can be compared to the rRNA - rDNA hybrid of Xenopus which has a density of 1.77 . Its DNA sequences complementary to the rRNA comprise $48 \%$ of the complete rDNA (17).

Ribosomal genes show characteristics of repetitious DNA. Repetitious DNA often behaves differently in isopycnic gradients than would be predicted by its $G+C$ content alone. Although $\mathrm{Ag}^{+}$usually binds preferentially to $\mathrm{G}+\mathrm{C}$ bases to increase buoyant density, the $\mathrm{rDNA}$ acts as a satellite in $\mathrm{Ag}^{+}$CS. SO, with very low $\mathrm{Ag}^{+}$binding. The mechanism for this decreased silver binding is not known, but this property distinguished rDNA in a further way in that it behaves as other repetitious human DNA's (for a review of repetitious DNA sec Reference 10$)$.

The low background and high specific activity achieved with our highly purified rRNA permitted us to examine various interesting karyotypes. These studies demonstrate examples of rDNA genes being lost from chromosomes which normally contain them and and of these genes being transferred to chromosomes which do not normally carry them. In situ hybridization provides a method to visualize specific gene alterations in relationship to cytogenetic changes.

In the normal karyotypes with our highly purified rRNA. our results are in agreement with the in situ hybridization results of Hendersen et al. (9) and Evans e't al. (5), who used other types of rRNA preparations. The ribosomal genes are confined to the acrocentric regions of the $D+G$ chromosomes. Our results are not in agreement with Pardoet al. (13), who found hybridization on the number 1 and 2 chromosomes.

Although in situ hybridization is a qualitative technique, it 


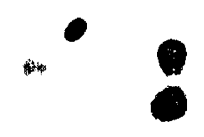

8

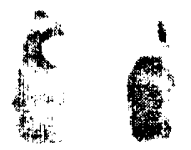

13
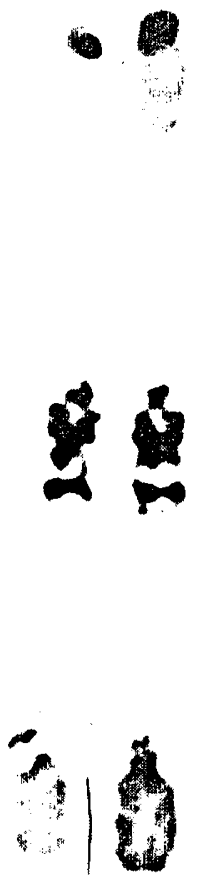
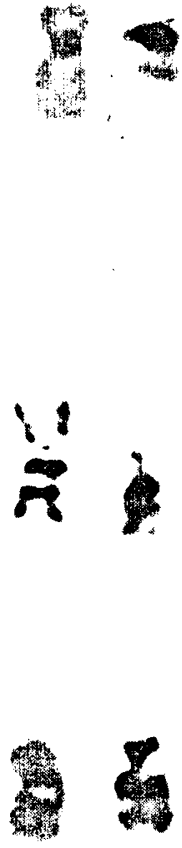

16

Fig. 7. Partial karyotype to compare Giemsa banding with the labeling of the D and 16 chromosomes. From Giemsa banding, center row, two abnormal chromosomes are noted: a deletion of chromosome 16 , and a chromosome 15 with an enlarged short arm. The long arm of 16 shows a prominent band which is not present in the normal 16 , and suggests that the point of exchange with 1.5 was below the centromere. The top row is an autoradiograph with a regular microscopic objective and the bottom row with phase contrast. In all 1.5 karyotypes studied, at least 1 of the 15 chromosomes did not show hybridization. However, inability to specifically identify the abnormal 15 does not permit us to say whether the 15 chromosome contains ribosomal DNA.

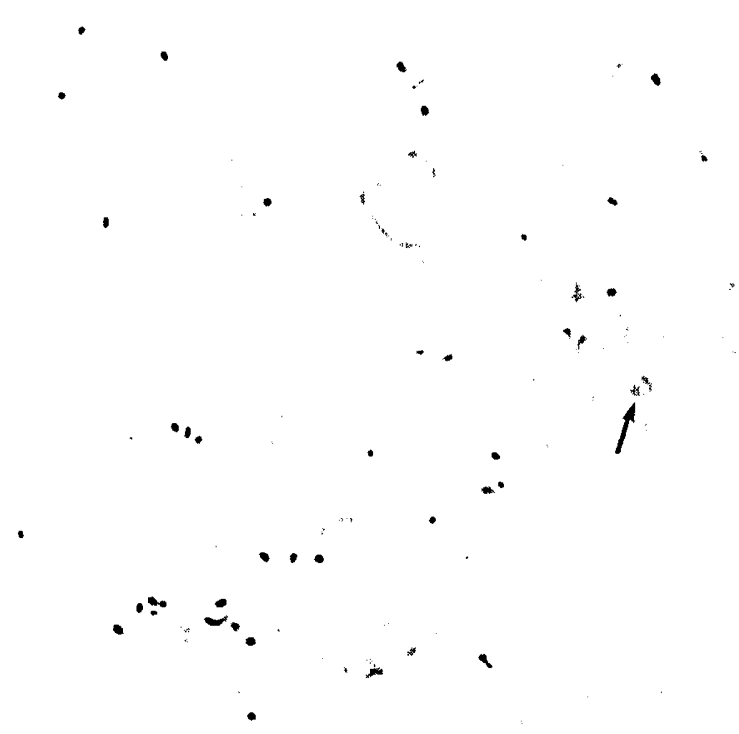

should also be considered as a quantitative tool. The diploid cell contains approximately $1.3 \times 10^{9} \mu \mathrm{g}$ of DNA. Our rRNA hats a specific activity of $1.7 \times 10^{i \mathrm{~d}} \mathrm{pm} / \mu \mathrm{g}$. Therefore, one would expect the hybridizable rRNA to have 6.5 disintegrations/day/ cell. Over the 60-day exposure period, we found the average grain count was 30 , or about $7 \%$ of the theoretically calculated disintegrations. Because the chromosomal DNA which is hybridized in situ is not in a uniform state, it is not possible to be completely satisfied with the guantitative inferences from this data. The ribosomal DNA is in an extended state in many cytologic preparations, which may facilitate irreversible denaturation. For the same reason, the rDNA which is in a less extended state in translocated chromosomes may not be irreversibly denaturated and not provide optimum hybridization.

One would question whether the clustered, repetitious nature of the genes and their distribution on nonhomologous chromosomes leads to an increased number of nonhomologous chromosomal exchanges. Each of the persons with variant chromosomes studied above had children with severe chromosomal abnormalities although they were normal themselves. It seems likely that the repetitious nature of rDNA leads to considerable sister

Fig. 8. Autoradiograph of the chromosomes from the individual with a highly fluorescent chromosome 15 . The variant chromosome, indicated by an arrow, is readily distinguished from the other acrocentric chromosomes by the dark Giemsa staining of the short arm after denaturation in alkali and renaturation. The other acrocentric chromosomes show hybridization whereas the variant chromosome does not. 

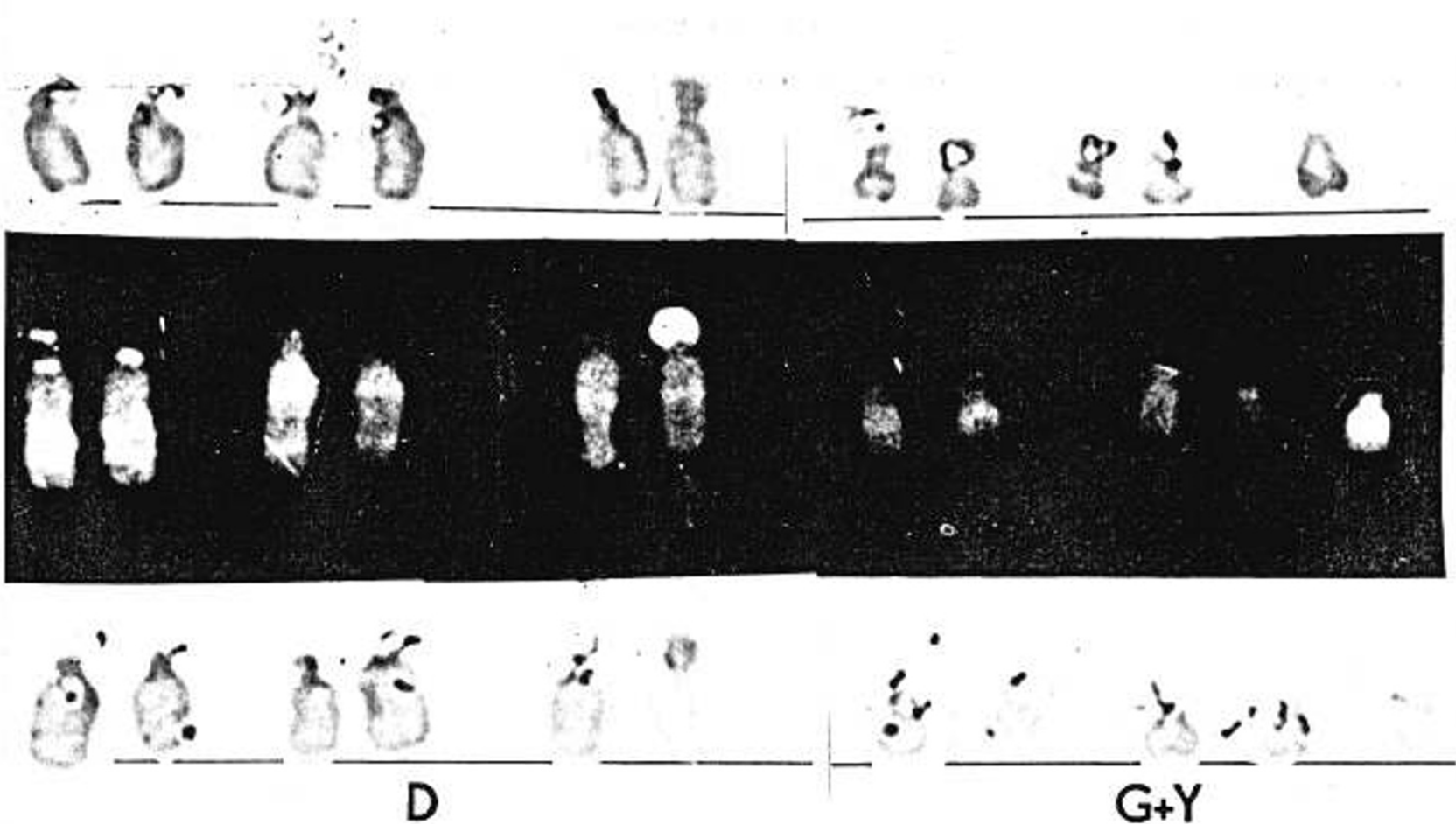

Fig. 9. A composite partial karyotype of the individual karyotyped in Figure 8 . The top and bottom rows are phase contrast microphotographs after in sim hybridization and autoradiography. The middle row demonstrates the fluorescent nature of the variant chromosome and its banding pattern. With in sim hybridization, the normal acrocentric chromosomes were always heavily labeled but the variant chromosome was never labeled.

chromatid exchange and is responsible for individual quantitative variations (16). Sister chromatid exchanges may provide a compensatory mechanism for increasing the overall level of rDNA when it is deleted from other chromosomes. As more detailed structure of the rRNA genes becomes known. We should be able to learn more about the events which lead to chromosomal variation and interaction. These studies are pursued with the assumption that as microscopic alterations in chromosome organization are important to understanding genetic disease, understanding the molecular level of gene organization provides further insight into genetic disease.

\section{REFERENCLS ANI) NOTISS}

1. Blohel. G., and Potter, V. R.: Ribosomes in rat liver. J. Mol. Biol., 28: 539 (1967).

2. Bross, K., and Krone, W.: On the number of ribosomal RNA genes in man. Humangenetik, 14: 137 (1972).

3. Brown. D. D., and Weber. C. S.: Genetic linkage of RNA-DNA hybridization. J. Mol. Biol.. 34: 661 (1968)

4. Brown, D. D.. Wensink, P. C., and Jordan, E.: Purification and some characteristics of 5S DNA from X'enopus lae'vis. Proc. Natl. Acad. Sci. U. S. A. 68: $3175(1971)$

5. Evans, H. J., Buckland, R. A., and Pardue, M. L.: Location of the genes coding for $18 \mathrm{~S}$ and $28 \mathrm{~S}$ ribosomal RNA in the human genome. Chromosoma (Berlin), 4s: 405 (1974)

6. Gall, J. G., and Parduc, M. L.: Formation and detection of RNA.DNA hybrid molecules in cytological preparations. Proc. Natl. Acad. Sci. U. S A., 63: $378(1969)$

7. Gillespie, D., and Spiegelman, S.: A quantitative assay for DNA-RNA hy- brids with DNA immobolized on a membrane. J. Nol. Biol., 12: 824 (196.5).

8. Guanti, G., and Petrinelli, P'.: rDNA and acrocentric chromosomes in man. Cell Diff.. 2: 319 (1974),

9. Henderson. A. S., Warburton, D., and Atwood, K. C.: Ribosomal DNA connectives between acrocentric chromosomes. Nature, 245: 95 (1973).

10. Jomes, K. W.: Satcllite DNA. J. Med. Genet., 10: 273 (1973).

11. Krooth, R. S.: Properties of diploid cell strains developed from patients with an inherited abnormality of uridine biosynthesis. Cold Spring Harbor Symp. Quant. Biol., 29: $189(1964)$

12. Mandell, J. D., and Hershey, A. D.: A fractionating column for analysis of mucleic acids. Anal. Biochem., 1: 66 (1960).

13. Pardo. D.. Luciani. J. M., and Stahl. A.: Localisation, par hybridation in situ, des genes des arn $28 S$ et ISS dans les chromosomes somatiques humains. Ann. Ginét., 18: 105 (1975).

14. Schmichel. R. K. Ouantitation of human ribosomal DNA: Hybridization of human DNA with ribosomal RNA for quantitation and fractionation. Pediat. Res.. 7: 5 (1973).

15. Schmichel. R. D.. Pomanski, A.. and llimebaugh, J.: A 16 y trisomy in a family with a balanced 15/16 translocation. Birth Defects: Original Article Series, Vol. 11, pp. 229-236. 1975

16. Tartof, $K$. D.: Uneyual mitotic sister chromatid exchange as the mechanism of ribosomal RNA gene magnification. Proc. Natt. Acad. Sci. U. S. A., 71: $1272(1974)$

17. Wallace, H., and Birnsticl, M. L.: Ribosomal cistrons and the nucleolar organizer. Biochem. Biophys. Acta, 114: 296 (1966).

18. This research was supported by National Institutes of Health Grant 5 RO1HI) $(1) 4.569-05$.

19. Requests for reprints should he addressed to: R. D. Schmickel, M.D., Birth Defects Lab, University Hospital, K-2015 Holden. Ann Arbor, Michigan 48109 (USA)

20. Received for publication August 11, 1976.

21. Accepted for publication January 27, 1977 